\title{
Draft: Standards for College Libraries 1975 Revision
}

Prepared by the ACRL Ad Hoc Committee to Revise the 1959 Standards: Johnnie Givens, Austin Peay State University (Chairman); David Kaser, Graduate Library School, Indiana University; Arthur Monke, Bowdoin College; David L. Perkins, California State University, Northridge; James W. Pirie, Lewis of Clark College; Jasper G. Schad, Wichita State University; and Herman L. Totten, School of Librarianship, University of Oregon.

Supported by a J. Morris Jones-World Book Encyclopedia-ALA Goals Award.

\section{Introduction}

This document presents Standards for assessing the adequacy of libraries serving liberal arts programs at the bachelors and masters degree levels. They may be applied also to libraries serving universities which grant fewer than ten doctoral degrees per year. ${ }^{*}$ They are not designed for use in two-year colleges, larger universities, independent professional schools, or specialized programs.

These Standards are organized on the basis of the major functions and components of library organization and services and are arranged as follows:
1. Objectives
2. Collections
3. Organization of Materials
4. Staff
5. Delivery of Service
6. Facilities
7. Administration
8. Budget

They were prepared by an ad hoc ACRL Committee to Revise the 1959 "Standards for College Libraries" with the support of a J. Morris Jones-World Book Encyclopedia-ALA Goals Award.

The Standards are an attempt to synthesize and articulate the aggregate experience and judgment of the academic library profession as regards requisite resources, services, and facilities for a minimal library program in a college. There are a number of additional areas where-

- Specifically these Standards address themselves to institutions defined by the Carnegie Commission as Liberal Arts Colleges I and II and Comprehensive Universities and Colleges I and II, in A Classification of Institutions of Higher Education (Berkeley, Cal., 1973). in standards would be desirable if it were possible to prepare them, but on which the Committee was unable to identify any consensus among librarians at this time. Such areas might include library productivity, measures of library effectiveness, and the requisite extent and configuration of non-print holdings. Research and experimentation in these matters should be encouraged so that it will be possible at some future time to prepare standards concerning them.

STANDARD 1:

OBJECTIVES OF THE LIBRARY

1 The college library shall develop an explicit statement of its objectives in accord with the goals and purposes of its parent institution.

1.1 The development of library objectives shall be the responsibility of the library staff, in consultation with students, members of the teaching faculty, and administrative officers.

1.2 The statement of library objectives shall be reviewed periodically and revised as needed.

\section{Commentary on Standard 1}

The administration and faculty of every college have a responsibility to examine from time to time their educational programs and to define the purposes and goals of the institution. Members of the library faculty share in this exercise, and they have thereafter the responsibility to promote library service consistent with institutional aims and methods. Successful fulfillment of this latter responsibility can best be attained when a clear and explicit statement of derivative library objectives is prepared and promulgated so that all members of the college community can understand and evaluate the appropriateness and effectiveness of library activities.

Preparation of library objectives is an obligation of the library faculty with the assistance of the rest of the library staff. In this effort, however, the library should seek in a formal or structured way the advice and guidance of students, of members of the teaching faculty, and of administrative officers. Library objectives should be kept current through periodic review and revision as needed.

In preparing its statement of objectives, the library staff should consider the evolution in re- 
cent decades of new roles for the American college library. In the nineteenth century the function of the college library was to serve passively as the repository for printed information needed for reference by students and faculty. Although the college library continues in the twentieth century to fill this traditional role, its resources have now been extended to embrace all forms of recorded information, and its proper purpose has been enlarged through changes in the scope of its curriculum and by new concepts of instruction. Thus it now serves as a complementary academic capability which affords to students the opportunity to augment their classroom experience with an independent avenue for learning beyond the course offerings of the institution. Even this instructional objective of the library, however, must be conceived and formulated within the overall academic purpose of the college.

\section{STANDARD 2:}

\section{The Collections}

The library's collections shall comprise all corpuses of recorded information owned by the college for educational, inspirational, and recreational purposes, including multi-dimensional, aural, pictorial, and print materials.

2.1 The library shall provide quickly a high percentage of such materials needed by its patrons.

2.1.1 The amount of print materials to be thus provided shall be determined by a formula (Formula A) which takes into account the nature and extent of the academic program of the institution, its enrollment, and the size of its teaching faculty.

\section{Commentary on Standard 2}

The records of intellectual endeavor appear in a wide range of formats. Books represent extended reports of scholarly investigation, compilations of findings, creative works, and summaries prepared for educational purposes. The journal has become the common medium for scientific communication and usually represents more recent information. Scientific reports in near-print form are becoming an even faster means of research communication. Documents represent compilations of information prepared by governmental agencies, and newspapers contain the systematic recording of daily activities throughout the world.

Many kinds of communication can be better and sometimes faster accomplished through such non-print media as films, slides, tapes, radio and television recordings, and realia. Microphotography is an accepted means of compact-

\section{FORMULA A-}

The formula for calculating the number of relevant print volumes (or microform volumeequivalents) to which the library should be able to provide prompt access is as follows:

1. Basic Collection

2. Allowance per FTE Faculty Member

3. Allowance per FTE Student

4. Allowance per Undergraduate Major or Minor Field

5. Allowance per Masters Field, When No Higher Degree Is Offered in the Field"

6. Allowance per Masters Field, When a Higher Degree Is Offered in the Field

7. Allowance per 6th-year Specialist Degree Field

8. Allowance per Doctoral Field *

$$
\begin{array}{r}
85,000 \text { vols. } \\
100 \text { vols. } \\
15 \text { vols. } \\
350 \text { vols. } \\
6,000 \text { vols. } \\
\\
3,000 \text { vols. } \\
6,000 \text { vols. } \\
25,000 \text { vols. }
\end{array}
$$

A "volume" is defined as a physical unit of any printed, typewritten, handwritten, mimeographed, or processed work contained in one binding or portfolio, hardbound or paperbound, which has been cataloged, classified, and/or otherwise prepared for use. For purposes of this calculation microform holdings should be included by converting them to volume-equivalents. The number of volume-equivalents held in microform should be determined either by actual count or by an averaging formula which considers each reel of microform as one, and five pieces of any other microformat as one volume-equivalent.

Libraries which can provide promptly 100 percent as many volumes or volume-equivalents as are called for in this formula shall, in the matter of quantity, be graded A. From 80-99 percent shall be graded B; from 65-79 percent shall be graded C; and from 50-64 percent shall be graded D.

\footnotetext{
"See Appendix I, "List of Fields" [to be published].
} 
ing many kinds of records for preservation and storage. Recorded information may also come in the form of manuscripts, archives, and machine-readable data bases. Each medium of communication provides unique dimensions for the transmission of information, and each tends to complement the others.

This inherent unity of recorded information, and the fundamental commonality of its social utility, require that, regardless of format, all kinds of recorded information needed for academic purposes by an institution be selected, acquired, organized, stored, and delivered for use within the library. This is the only way in which the institution's information resources can be articulated and balanced for the greatest benefit of the entire community.

It is less important that a college hold legal title to a large quantity of library materials than that it be able to supply them quickly-say within fifteen minutes - as by contract with an adjacent institution or by some other means. An institution which arranges to meet a part of its library responsibilities in this way, however, must take care that in doing so it not create supernumerary or unreimbursed costs for another institution and that the materials so made available are relevant to its own students' needs.

Since a library book collection once developed and then allowed to languish loses its utility very rapidly, continuity of collection development is essential. Experience has shown that even after collections have attained sizes required by this Standard, they can seldom retain their requisite utility without sustaining annual gross growth rates, before withdrawals, of at least five percent.

Higher education has thus far had too little experience with non-print library materials to permit tenable generalizations to be made about their quantitative requirements. Since consensus has not yet been attained among educators as to the range, extent, and configuration of non-print services which it is appropriate for college libraries to offer, no generally applicable formulas are possible here. It is assumed, however, that every college library should have non-print resources in a quantity commensurate with its print holdings and appropriate to institutional needs.

The goal of college library collection development should be quality rather than quantity. A collection may be said to have quality for its purpose only to the degree that it possesses a portion of the bibliography of each discipline taught, appropriate in quantity both to the level at which each is taught and to the number of students and faculty members who use it. Quality and quantity are separable only in theory: it is possible to have quantity without quality; it is not possible to have quality without quantity defined in relation to the purposes of the institution. No easily applicable criteria have been developed, however, for measuring quality in library collections.

The best way to assure quality in a college library collection is to gain it at point of input. Thus rigorous discrimination in the selection of materials to be added to the library's holdings, whether as purchases or gifts, is of considerable importance. Care should be exerted to select a substantial portion of the titles listed in the standard, scholarly bibliographies reflecting the curriculum areas of the college and supporting general fields of knowledge. A number of such subject lists for college libraries have been prepared by learned associations. Among general bibliographies Books for College Libraries will be useful especially for purposes of identifying important retrospective titles. For current additions, provision should be made to acquire a majority of the significant new publications reviewed in Choice. Generous attention should be given also to standard works of reference and to bibliographical tools which provide access to the broad range of scholarly sources as listed in Winchell's Guide to Reference Books. Institutional needs vary so widely for periodical holdings that quantitative standards cannot be written for them at this time, but in general it is good practice for a library to own any title that is needed more than four times per year. Several good handlists have been prepared of periodical titles appropriate for college collections.

College library collections should be evaluated continuously against standard bibliographies and against records of their use, for purposes both of adding to the collections and identifying titles for prompt withdrawal once they have outlived their usefulness to the college program. Every book in a college library should be able to "prove" its right to be there in terms of the institution's current or anticipated academic program; when a book can no longer do this it should be retired in favor of a book which can do so.

Although in the last analysis the library staff must be responsible for the scope and content of the collections, it can best fulfill this responsibility with substantial help and consultation from the teaching faculty and from students. Of greatest benefit to the library is continuing faculty assistance in defining the literature requirements of the courses in the curriculum, definitions which should take the form of written selection policies. In addition, members of the teaching faculty may participate in the selection of individual titles to be obtained. If this latter activity, however, is carried out largely by the library, then the teaching faculty should review the books received both for their appropriateness and the quality of their contents. 


\section{College \& Research Libraries}

\section{Volume 35, 1974}

PUBLISHED BY THE ASSOCIATION OF COLLEGE AND RESEARCH LIBRARIES, A DIVISION OF THE AMERICAN LIBRARY ASSOCIATION 


\author{
(including $C \& R L$ News issues)
}

\title{
Prepared by Caroline LaMotte Webb
}

\section{ABBREYIATIONS}

Standard abbreviations for names of organizations, ALA, ACRL, LC, etc., are alphabetized as if spelled out. Other abbreviations:

$\begin{array}{ll}\text { appt. } & \text {-appointment } \\ \text { bibliog.(s) } & \text { - bibliography (-graphic) } \\ \text { coll.(s) } & \text {-college(s) } \\ \text { ed. } & \text { - editor, edition } \\ \text { l.(s), In.(s) } & \text { - library(ies), librarian(s) } \\ \text { port. } & \text {-portrait } \\ \text { rev. } & \text {-review(er) } \\ \text { s (before page numbers) } & \text {-C\&RL News issues } \\ \text { univ.(s) } & \text {-university(ies) }\end{array}$

\section{A}

Abell, Millicent, port. \& prof., s $16-17$

Abstracts, 63-68; 221-23; 304-6

"Academic business lns,-authors sought," s141

"The academic job crisis: a unique opportunity, or business as usual?," Moffett ( $\mathrm{C} d R L$, May 1973), comments, 48, 52-53

"The academic 1. and its environment," Lynch, 126-32; com1ment, 297-98

"Access denied? The use of manuscript material," introduction, Walton, 285

Access to Periodical Resources: A National Plan, Palmour, Bellassai, and Gray, rev. of, 457-58

The Acquisition of L. Materials, Hug, rev. of, 376-77

Acquisitions, s5-6; s29; s5354; s100-102; sl29; s159-60; s185-87; s222-23; s253-55; s275

Adediran, B. O., "Centralization of univ, 1. services: some compelling factors in Nigerian univs." $360-63$

"Allocating the book budget: a model," Kohut, 192-99; comment, 370-71

"ALA/ACRL representatives at academic ceremonies and meetings," s137

ALA/Social Responsibilities Round Table/Task Force on the Status of Women, s180

"ALA Goals Award to Standards project," s 182

"ALA - is it time for an alternative?," Dougherty, editorial (C\&RL, May 1973), comment. 47-48
"ALA proposes new dues structure," \$49-50

Anderson, John F., rev. (The Disadvantaged and L. Effectiveness), 214

Applications of Computer Technology to L. Processes: A Syllabus, Becker and Pulsifer, rev. of, 135-36

"Applying "management by objectives' to the univ. 1.," Johnson (C\&RL, Nov. 1973), comment, 296-97

Appointments, s17-19; s43; s6566; s89-91; s117-18; s141-42. s168-69; s201-2; s237-39; s263-65; s306-9

"An approach to collection inventory," Clark, 350-53

The Area Specialist Bibliographer: An Inquiry into His Role, Stueart, rev. of, 56-57

Archives Procedural Manual, rev. of, 373-74

"Art 1., collections in North America," s 115

ACRL, additional nominating committees, s3; s25

ACRL, additional nominees for offices $1974 / 75$, s3

ACRL, "Annual report of the president, 1973-74," s154-57

ACRL, Art Section, s231

ACRL, Board of Directors, annual meeting, New York, July 7-13, 1974, "highlights," s18283

ACRL, Board of Directors, midwinter meeting, Chicago, 11l., Jan. 21-24, 1974 , actions, s5152

ACRL, Coll. Ls. Section, s23132; bylaws, s232-33

ACRL, committee to revise the 1959 standards for coll. Is., meeting, s3
ACRL, Community and Junior Coll. Ls. Section, bylaws, s23536

ACRL, "Hearings held on standards revision" s51

ACRL, Law and Political Science Section, "Attention, LPSS members," s82

ACRL, midwinter meeting, Chicago, Ill., Jan. 20-26, 1974 , schedule of meetings, si-2

ACRL, Rare Books and Manuscripts Section, preconference, $s 77$

ACRL, Rare Books and Manuscripts Section, Committee on Manuscripts Collections, "Statement on access to original research materials in ls., archives, and manuscript repositories," sI14; "Statement on the reproduction of manuscripts and archives for noncommercial purposes," s115

ACRL, "Standards for faculty status for coll, and univ. Ins." sl12-13

ACRL/AAC/AAUP, "Statement on faculty status of coll. and univ. lns.," s26; "Organizations endorsing the statement on faculty status," s27, s109; correction, s65

"ACRL chapter developments," s252

"ACRL chapter news," s274

ACRL committee volunteer form, s247

"ACRL conference highlights, s221

"ACRL goals study," s79

"ACRL internship program," $s 220$

"ACRL needs volunteers!" s24546 
"ACRL New York programs," s73-75

"ACRL nominees for offices, 1975/76," s273-74

“ACRL officers for $1974 / 75$, ," s $177-79$

"ACRL publications in librarianship," s 100

Auerbach on Microfilm Renders Printers, rev, of, 55-56

"Automation of technical services: Northwestern's experience," Horny, 364-69

Axford, H. William, "An overlooked cost of achieving a participatory environment," editorial, 5-6; comment, 211-12 295-96; port., sI77

\section{B}

Baaske, Jan, Don L. Tolliver and Judy Westerberg, "Overdue policies: a comparison of alternatives," 354-59

Balay, Robert, letter to the ed. (C\&RL, July 1973), comment. 48-50

Ball, Joyce, rev, (The Monthly Catalog of U.S. Government Publications; An Introduction to Its Use), 134-35; rev (Sources of Information in the Social Sciences: A Guide to the Literature, 2 ed, 372-73

Barron, Tilton M., letter to the ed., 298

Becker, Joseph and Pulsifer, Josephine S., Application of Computer Technology to L. Processes: A Syllabus, rev. of, 135 36

Beeler, Richard J., "Late-study areas: a means of extending 1 . hours," 200-203

Bellassai, Marcia C., Gray, and Palmour, Access to Periodical Resources: A National Plan, rev. of, 457-58

"Black book reviewing: a case for 1. action" Shockley, 16-20

Blum, Fred., port. \& prof., s 141

Boissonnas, 'Christian M., "Employee suggestions: alternative course of action for ls.," 109 13

Bommer, Michael and Bernard Ford," $\mathrm{A}$ cost-benefit analysis for determining the value of an electronic security system," 270-79

Boone, Morell D., rev. (Research Ls. and Technology: A Report to the Sloan Foundation), 375 76

Book Clubs \& Printing Societies of Great Britain and Ireland Williams, rev. of, 377-78

Book Reviews, 55-61; 134-40; 214-18; 299-303; 372-80; 457 61

Booz, Allen and Hamilton, Inc. Organization and Staffing of the Ls. of Columbia Univ., rev. of 300-302

Borko, Harold, ed., Targets for Research in L. Education, rev. of, 139

Bosseau, Don L., port. \& prof., s117

Boyer, Calvin James, The Doctoral Dissertation as an Information Source: A Study of Scientific Information Flow, rev. tracts for 1. materials: an analysis of the attendant dysfunctional consequences," 86-94

Braverman Miriam, letter to the ed. 50-51

British Academic Ls., Neal, et al., rev. of, 214-15
Brown, Timothy A., rev. (Planning-Programming-Budget System (PPBS)), 215-16

Burke John Gordon and Wilson. Carol Dugan, The Monthly Catalog of U.S. Government Publications; An Introduction to Its Use, rev. of, 134-35

Butler, Lucius $\mathbf{A}_{1}$, and Pearson, Learning Resources Centers: Selected Readings, rev. of, 58 59

Barry, James W., rev. (Reader in Medical Librarianship), 60-61

\section{C}

"Captain serves New Jersey academic Is." s50

Cargill, Jennifer S., letter to the ed., 133

"Centralization of univ. 1. services: some compelling factor in Nigerian univs." Adediran 360-63

A Challenge for Academic $L s$.; How to Motivate Students to Use the L., Lee, rev. of, 217 18

"Change! Change! Change!," Painter, editorial, 161-62

Churchwell, Charles D., port. \& prof., s199-201

"The civility of scholars," McFeely, 286-90

Clark, Jay B., "An approach to collection inventory," $350-53$

Coburn, Louis, Library Media Center Problems, Case Studies, rev. of, 136-37

"C $d R L$ News editorship changes," s269

"College 1. standards: questions and answers," s249-50

Collins, Mary Frances, port., s269

"CBS license to National Archives," s 125

"CBS sues Vanderbilt," s63

Computer-Based Reference Service, Mathies and Watson, rev. of, $379-80$

Cook, Donald C. rev (Methods of Financing Interlibrary Loan Services; A System for Inter-L Communication (SILC); Ac cess to Periodical Resources: A National Plan), 457-58

"A cost-benefit analysis for determining the value of an electronic security system," Bomme and Ford, 270-79

\section{D}

Dahl-Hansen, Abby, port. \& prof., $s 65$

Danton, J. Periam, The Dimensions of Comparative Librarianship, rev. of, 215; rev. (International and Area Studies Librarianship, Case Studies), 372

Death, s91; s118; s143; s169; s203; s239; s309

DePriest, Raleigh, letter to the ed. , 48-50

The Dimensions of Comparative Librarianship, Danton, rev. of 215

Directory of L. Reprographic Services, s272

The Disadvantaged and L. Effectiveness, Lipsman, rev of 214

Discrimination Against Women; Congressional Hearings on Equal Rights in Education and Employment, Stimson, rev. of, 59-60

Dix, William, "The financing of the research 1.," 252-58

The Doctoral Dissertation as an Information Source: A Study of
Scientific Information Flow, Boyer, rev. of, 374-75

Dosa, Marta L., Libraries in the Political Scene, rev. of, 46061

Dougherty, Richard M., “ALAis it time for an alternative?, editorial (C\&RL, May 1973) comment, 47-48; "Exchanging old myths for new," editorial 85; "Looking forward/looking back," editorial, 241

"Dougherty resigns as CRL editor," 551

Downs, Robert B., "Library resources in the U.S.," 97-108; comment, 298

Doyle, James, rev. (Library Media Center Problems), 136-37

"Draft: guidelines for branch ls. in colls. and univs." $s 281-83$

"Draft: standards for coll. Is. 1975 revision," s284-86, s299305

DuBois, William, letter to the ed., 295-96

Dudley, Norman, rev. (The Area Specialist Bibliographer), 56-57

Dunkin, Paul S., rev. (The Universal Decimal Classification), 378-79

Dunn, J. D., and Vaughn, "A study of job satisfaction in six univ. Is." 163-77

"The dynamics of the 1 environment for professional staff growth," Weber, 259-67

\section{E}

Eaton, Nancy L., rev. (Non-Book Materials Cataloging Rules), 299-300

Edelman, Hendrik, rev. (The Acquisition of L. Materials), 37677

"Editorial projects as derivative archives," Simon, 291-94

"Effective group process for ls. a focus on committees," Tarr, 444-52

Ellsworth, Ralph E., Academic L. Buildings, A Guide to Architectural Issues and Solutions. rev. of ( $C \& R L$, Sept. 1973) comment, 53-54; letter to the ed., 53-54

"Employee suggestions: alternative course of action for 1s.," Boissonnas, 109-13

"ERIC/CLIS merges," s74

"EXCHANGE, anyone?," Stueart editorial (C\&RL, Sept. 1973), comments, 51,52

"Exchanging old myths for new," Dougherty, editorial, 85

\section{F}

Fair, Judy H., rev, (The Library of Congress), 458-59

Farley, Richard A., port, \& prof, s199

Fields, Dennis C. "Library management by objectives: the humane way," 344-49

Film L. Techniques, Harrison, rev. of, 302-3

"The financing of the research 1.," Dix, 252-58

"Financing system of USSR univ. ls." Peep and Sinkevicius, 17883, comment, 371

Ford, Bernard and Bommer, “A cost-benefit analysis for determining the value of an electronic security system," 270-79

Ford, Stephen, The Acquisition of L. Materials, rev. of, 376-77

"Ford grants $\$ 6$ million to continue CLR programs," s 180 
Forrest, Kathryn S., port. \& prof., s 89

Foskett, A. C., The Universal Decimal Classification: The History, Present Status, and Future Prospects of a Large General Classification Scheme, rev. of, $378-79$

"A framework for a comparative analysis of l. work," Lynch, $432-43$

"From economic to political analysis of 1 . decision making," Raffel, 412-23

Fussler, Herman H., Research Ls. and Technology: A Report to the Sloan Foundation, rev. of, 375-76

\section{G}

Gherman, Paul M., letter to the ed. , 211-12

Giles, Louise, port., s177-78

"Good will and confidence," Johnson, editorial, 401

Goodrum, Charles A., The Library of Congress, rev. of, 458 59

Gration, Selby U, and Arthur P. Young, "Reference-bibliographers in the coll. 1.," 28-34; comment, 133; 212-13

Gray, Lucy M., Palmour and Bellassai, Access to Periodical Resources: A National Plan, rev. of, 457-58

\section{$\mathbf{H}$}

Haak, John R., rev. (A Challenge for Academic Ls.), 217 18

Hanson, Stephen L., letter to the ed., 211

Harrelson, Larry E., "Large ls. and information desks," 21-27

Harris, Michael H., "Intuition, research, and the academic l," editorial ( $C \& R L$, July 1973) comments, 47-48, 52; rev. (Targets for Research in L. Education), 139

Harrison, Helen P., Film L. Techniques, rev, of, 302-3

"Harvard, Yale, Columbia, NYPI form consortium," s97

Hayes, Robert M., A System for Inter-L. Communication (SILC) rev. of, 457-58

Heinritz, Fred, "Rate of Growth for 1 . collections," 95-96

Hendrick, Clyde and Marjorie E Murfin, "Project 1 . ripoff: a study of periodical mutilation in a univ. 1." 402-11

Hendricks, Donald D., rev. (Proceedings of the 1972 Clinic on L. Applications of Data Pro cessing: Applications of OnLine Computers to L. Problems), 134

Hoadley, Dr. Irene Braden, port $\&$ prof., s263

Horny, Karen, "Automation of technical services: Northwestern's experience," 364-69

"How much, how often?," Marshall. 453-56

Hug William E. Strategies for Change in Information Programs, rev. of, 376

\section{I}

Inforasia correction, 527 (see C\&RL News, Nov. 1973, s275)

Inside Washington, s77-78; s99; s127-28; s157-58; s181-82; s217-19; s251-52; s271-72

International and Area Studies
Librarianship, Case Studies, Sable, rev of, 372

"Intuition, research, and the academic l.," Harris, editorial (C\&RL, July 1973), comments, $47-48,52$

Johnson, Edward R., "Applying 'management by objectives' to the univ. 1." (C\&RL, Nov. 1973), comment, 296-97

Johnson, Richard D., "Editorial," 321; "Good will and confidence," editorial, 401; port. s153 Johnson

s 153

Jordan, Casper L., port. \& prof. s306

Josey, What Black Lns. Are Saying, rev. of (C⿺RL, July 1973), comment, 50-51

Joyce, Donald Franklin, letter to the ed., 54 (correction notice)

\section{$\mathbf{K}$}

Kaser, David, rev. (Libraries in the Political Scene), 460-61; "Library access and the mobility of users," 280-84; rev. Book Club o' Printing Societies of Great Britain and Ireland), 377-78; rev. (The $\mathrm{D} i$ mensions of Comparative Librarianship), 215

Kohut, Joseph, "Allocating the book budget: a model," 19299; comment 370-71; letter to the ed., $370-71$

\section{L}

Lancaster, F. Wilfred, ed., Proceedings of the 1972 Clinic on L. Applications of Data Processing: Applications of OnLine Computers to L. Problems, rev. of, 134; Proceedings of the 1973 Clinic on L. Applications of Data Processing: Networking and Other Forms of Cooperation, rev, of, 380

"Large Is. and information desks," Harrelson, 21-27

"Late-study areas: a means of extending 1. hours," Beeler, 200203

Learning Resources Centers: Selected Readings, Pearson and Butler, rev, of, 58-59

Lederer, Norman, rev, (What Black Lns. Are Saying), (C\&RL, July 1973), comment, 50-51

Lee, Sul H. A Challenge for Academic Ls.' How to Motivate Students to Use the $L$., rev, of, 217-18; PlanningProgramming-Budgeting System (PPBS): Implications for L. Management, rev. of, 21516

Leitz, Richard, letter to the ed., 52

Leopold, Carolyn C., rev, (Learning Resources Centers), 58-59

Letters, 47-54; 133; 211-13; 295$98 ; 370-71$

Libraries in the Political Scene, Dosa, rev, of, 460-61

"Library access and the mobility of users," Kaser, 280-84

Library Association Media Cataloging Rules Committee, NonBook Materials Cataloging Rules; Integrated Code of Practice and Draft Revision of the Anglo-American Cataloging
Rules British Text Part III, rev. of, 299-300

"Library cooperation: the ideal and the reality," Reynolds, 424-31

"Library cooperative developments," s125-26

"Library management by objectives: the humane way," Fields, 344-49

"Library management intern program," s58

"Library manpower requirements studied," s98

Library Media Center Problems, Case Studies, Coburn, rev. of, 136-37

The Library of Congress, Goodrum, rev. of, 458-59

"Library resources in the U.S." Downs, 97-108; comment, 298

"Library service from numerical data bases: the 1970 census as a paradigm," Rowe and Ryan, ipsman, Claire K. The Disadvantaged and L. Effectiveness, rev. of, 214

"Looking forward/looking back," Dougherty, editorial, 241

Lubans, John, Jr., rev. (Computer-Based Reference Service), 379-80

Lynch, Beverly P., "The academic 1. and its environment," 126 32; comment, 297-98; "A framework for a comparative analysis of l. work," 432-43

\section{Mc}

McClure, Charles R., rev. (Archives Procedural Manual) 373-74; rev. (Reader in Government Documents), 140

McDonald, John P., port. \& prof. s237

McFeely, William S., "The civility of scholars," 286-90

McGrath, William E., letter to the ed. 370 ; comment, 371

\section{M}

"The management review and analysis program: an assisted self-study to secure constructive change in the management of research ls." Webster, 114-25

Marchant, Maurice P., letter to the ed., 297-98

Marshall, Peter, "How much, how often?" 453-56

Mason, Ellsworth, rev. (Organization and Staffing of the Ls. of Columbia Univ.), 300-302

Massman, Virgil F., letter to the ed., 52-53

Mathies, Lorraine M., and Watson, Peter G., Computer-Based Reference Service, rev. of, 379 80

Methods of Financing Interlibrary Loan Services, Palmour, Olson and Roderer, rev. of, 457-58

Miller, Laurence, "The role of circulation services in the major univ, 1.," (C\&RL, Nov. 1973), comment, 212

Moffett, W. A., "The academic job crisis: a unique opportunity, or business as usual?" (C\&RL, May 1973), comments, 48, 52-53

Monke, Arthur, s127

"Monke joins Committee to $\mathrm{Re}$ vise Standards," s127

The Monthly Catalog of U.S Government Publications; An Introduction to Its Use, Burke and Wilson, rev. of, 134-35 

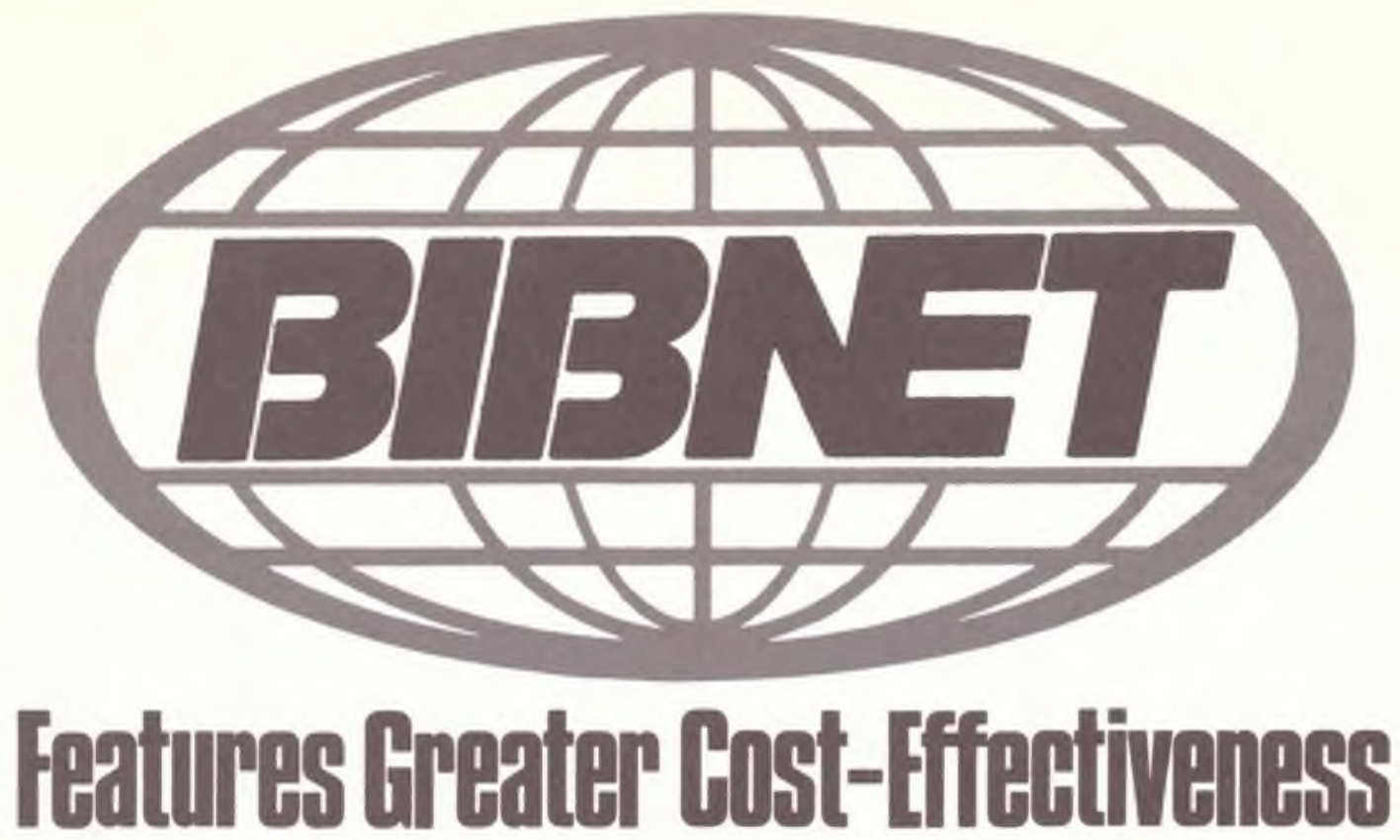

\section{HILHER VALUE...}

- 3,550,000 items cataloged by L. C. searchable on-line

- search by: LC card number, ISBN, ISSN, keywords in title, author, subject, classification number, series note, and many other data elements

* Note: High search power combined with broad data coverage reduces "no-hits" to a minimum saving original cataloging costs of $\$ 10.00$ or more per item.

- catalog records retrieved meet national standards

- cards produced automatically without mail delay

- holder codes displayed within consortium group

- BIBNET terminals access over 20 other on-line data bases

$\star$ BIBNET services are available to all sectors throughout the nation: non-profit, profit, private, and public - everywhere people have a need for libraries.

\section{LOWER EOST ...}

- no special telephone lines to install

- dial-up instead of continuous communication charges

- no administrative overhead or R\&D assessments

- LC retrospective cataloging added at your request without extra charge

- cards at $21 / 2 c$ each

- group discounts on use charges 


\section{At last, one source of subject access to 20}

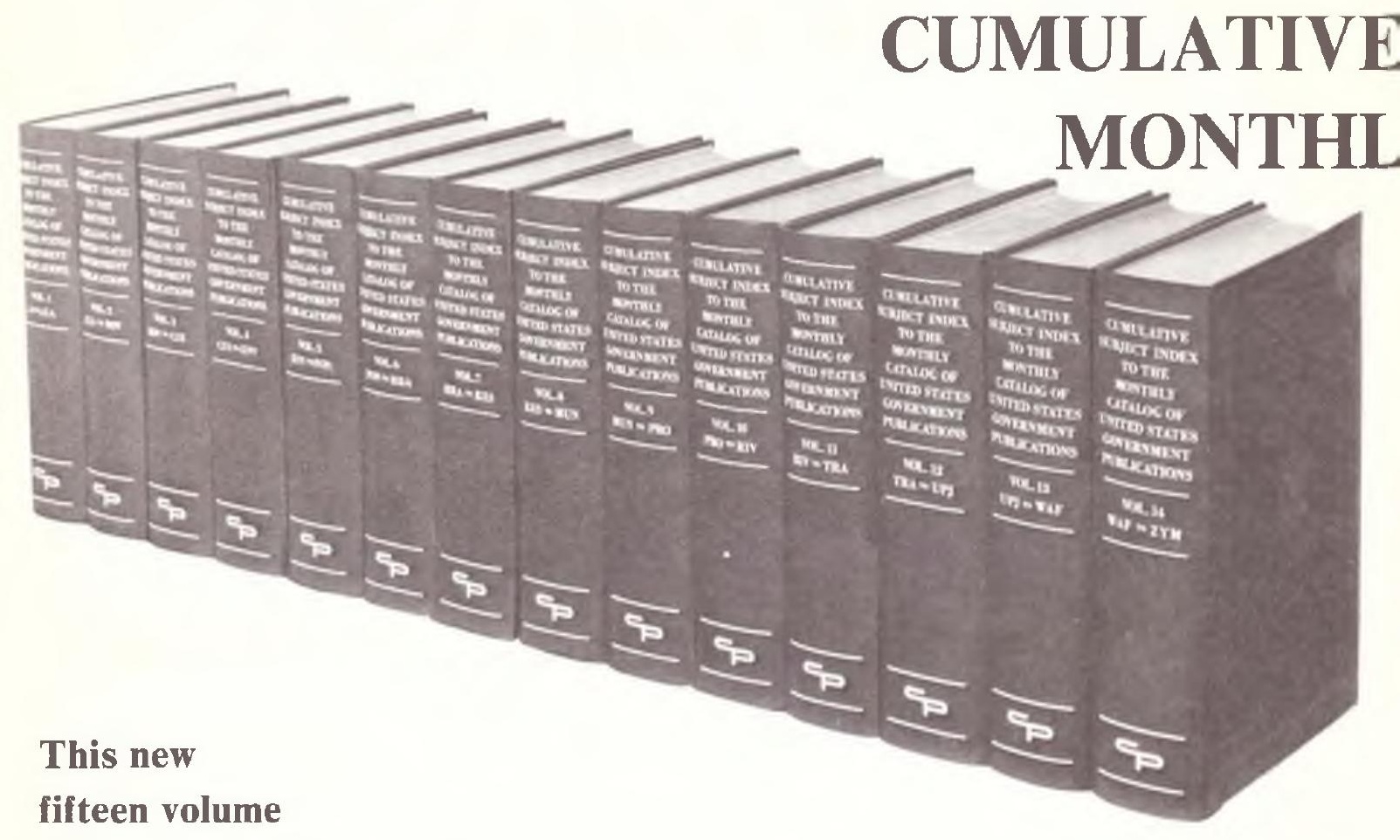

single-alphabet index set

is the largest and most comprehensive subject

index to U.S. Government publications ever produced.

It can be purchased either by itself, or as the key component of our U.S. MONTHLY CATALOG SUBJECT REFERENCE SYSTEM

This complete system contains the Index plus 106 full size reprint volumes of the Monthly Catalog, issued during the years 1895-1962 -including the 30 volume "Classes Added" Edition (for 1895-1924) to which previously missing Superintendent of Documents Class Numbers were added under the supervision of Mary Elizabeth Poole. All reprint volumes are specially bound and marked for easiest use with the Cumulative Subject Index. Send for our free brochure on the Monthly Catalog Subject Reference System. It includes details of our unique offer of free "interim use" microfilm reels which can be used before (and after) complete sets of reprint volumes are delivered. Meanwhile, the Cumulative Subject Index may also be purchased in the Combined Reference Edition which, as explained on the coupon, includes the complete Monthly Cata$\log$ on Microfilm.

Note: On January 15, 1975, The Pre-Publication Price Goes Up From $\$ 965$ To $\$ 1,160$ We know this is a healthy $20 \%$ price increase.

What we want you to know is that the content of the index volumes has increased an even healthier $\mathbf{3 0 \%}$ since we first set the price (based on an estimate of 10,000 two-column pages in 14 volumes). But by the time we got to "Zythia" (the last entry) we had produced more than 13,000 pages, which will be bound in 15 volumes. Put another way, the set increased from some 1.4 million lines to more than 1.8 million lines, and that's a lot of cumulative indexing at any price. 


\section{th Century U.S. Government Publications}

\section{SUBJECT INDEX TO THE}

\section{CATALOG OF UNITED STATES GOVERNMENT PUBLICATIONS 1900-1971}

"In this ambitious new library tool, cumulative access is brought for the first time to the overwhelming majority of United States Government publications issued during the period 19001971. In this, it is an accomplishment unrivaled in size and scope. Documents librarians will find it a new and convenient time-saver and one which should offer them an additional means of providing an expanded Government publications service to their patrons."

from the Foreword by Carper W. Buckley

U.S. Superintendent of Documents, $1952-1970$

The unique new CUMULATIVE SUBJECT INDEX will eliminate 34 search steps which were formerly necessary to trace subjects through these indexes to 20th Century U.S. Government publications:

-21 Biennial Document Catalogs (1900-1940),

- 2 Decennial Indexes (1941-1960), and

-11 Annual Indexes (1961-1971).

All subject entries in the fifteen volume cumulative index were accumulated from 81 separate sources in the Monthly Catalog series and merged into one reference set. These sources include: 48 Annual Indexes to the Monthly Catalog, 2 Decennial Indexes, (1941-1950; 19511960), 1 Six-month Index, and 30 Monthly Catalogs for which no annual indexes were made.

\section{USE THIS CONVENIENT COUPON TO RECORD YOUR ORDER NOW}

To: Carrollton Press, Inc.

1647 Wisconsin Avenue, N.W., Washington, D.C. 20007

Please record our order for the following:

$\square$ The Cumulative Subject Index to the Monthly Catalog of United States Government Publications, 1900-1971 in 15 hardcover volumes (Until January 15, 1975) $\$ 965.00$

The full text of the Monthly Catalog as follows:

$\square$ on 56 reels of $16 \mathrm{~mm}$ microfilm $1895-1971$ $\$ 650.00$

$\square$ in 106 full size reprint volumes, 1895-1962 $\$ 5,570.00$ including:

$\square$ Set I Classes Added Edition 1895-1924 (30 volumes) _...... \$1,970.00 Set II, 1925-1935 (22 volumes) $\quad \$ \$ 15.00$

Set III, 1936-1944 (18 volumes) Set IV, 1945-1953 (18 volumes)

Set V, 1954-1962 (18 volumes)
$\$ 915.00$

$\$ 915.00$

$\$ 915.00$

$\square$ Individual years of the Monthly Catalog, 1895-1924 (Classes Added) @ \$68.00 per volume (one volume per year); $1925-1962$ @ \$55.00 per volume (two volumes per year)

Please send us your free brochure describing the U.S. Monthly Catalog Subject Reference System.

NAME

ADDRESS

CITY

STATE ZIP 

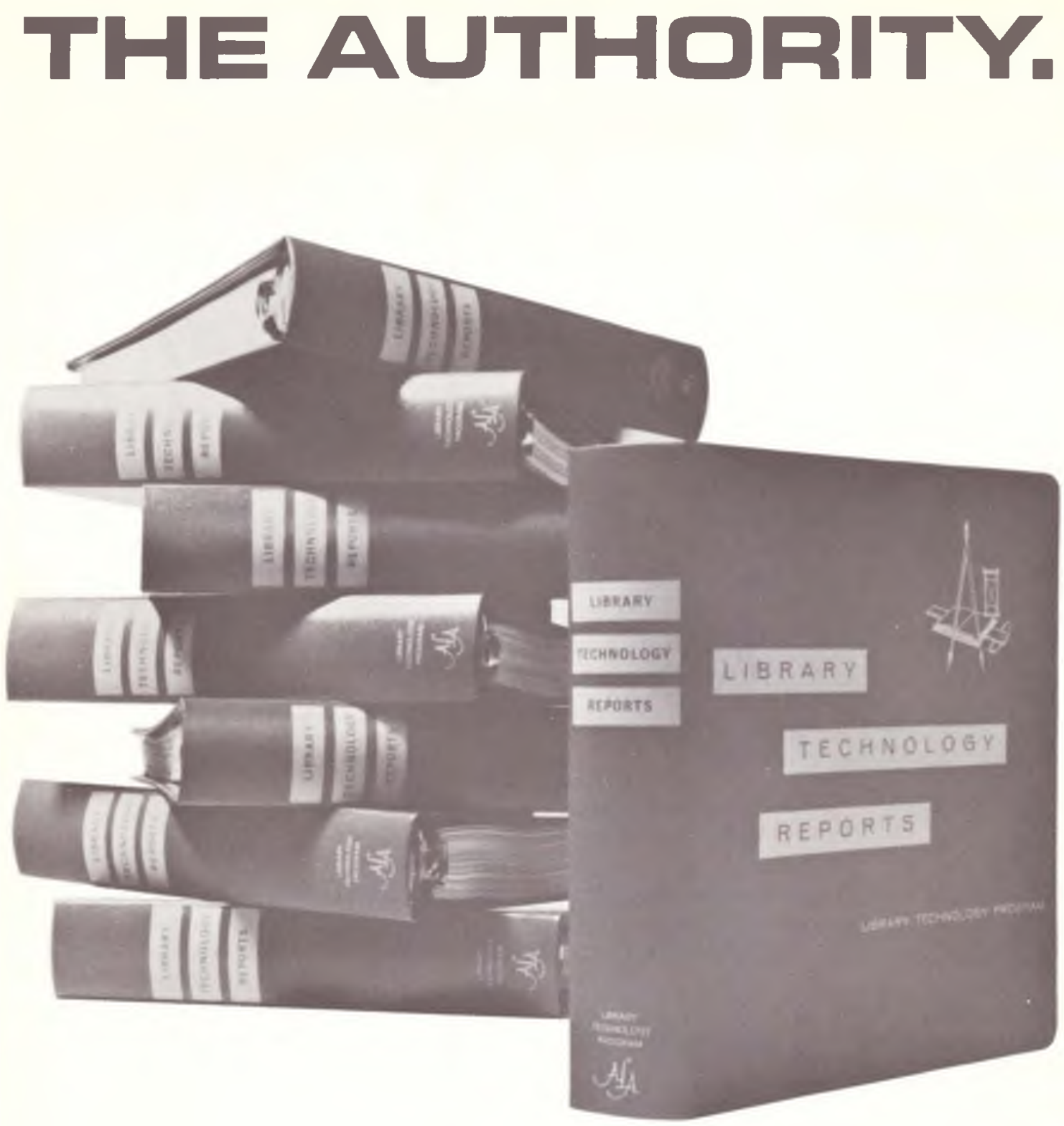

When you need objective information on library equipment, furniture, and supplies, there is only one published authority-Library Technology Reports.

Library Technology Reports is a unique bimonthly consumer publication of the American Library Association. LTR is designed to provide critical, objective evaluations of products used in libraries, media centers, and other educational institutions.
Testing and evaluation are conducted by nationally recognized independent testing laboratories and consultants, among which are R. A. Morgan Company (microform readers); United States Testing Company (audiovisual equipment); William R. Hawken Associates (microform reader/printers); and Buyers Laboratory Inc. (photocopiers, typewriters, steel library shelving, and library furniture).

For additional information and a sample issue, write to: 
Murfin Marjorie E, and Hendrick, "Project 1. ripoff: a study of periodical mutilation in a univ. 1.,"402-11

\section{$\mathrm{N}$}

National L. of Canada, Resources Survey Section, Research Collections in Canadian Ls., rev. of, 459-60

Neal, Kenneth William et al., British Academic Ls., rev. of, 214-15

Nettleman, James, letter to the ed., 133

New England Coll. and Research Lns., meeting, s4

News From the Field, s5-15; s2942; s53-64; s79-87; s100-107; s 129-36; s 159-68; s $185-97$; s222-31; s253-62; s275-80

News From the Sections, s23132

Niilus, Walter E, letter to the ed., 371

Nitecki, Joseph Z., rev. (Reader in L. Cooperation), 137-39

Non-Book Materials Cataloging Rules; Integrated Code of Practice and Draft Revision of the Anglo-American Cataloging Rules British Text Part III, prepared by the L. Association Media Cataloging Rules Committee, 299-300

Novak, Gloria J., rev (Academic L. Buildings, A Guide to Architectural Issues and Solutions, Ellsworth) (C\&RL, Sept. 1973), comment, 53-54

\section{$\mathrm{O}$}

O'Connell, Thomas F., rev. (Research Collections in Canadian Ls.), 459-60

O'Hara, Frederick J., ed., Reader in Government Documents, rev. of, 140

Olson, Edwin E., and Roderer and Palmour, Methods of $F i$ nancing Interlibrary Loan Services, rev. of, 457-58

Organization and Staffing of the Ls. of Columbia University. prepared by Booz, Allen \& Hamilton, Inc., rev. of, 300302

"Organizations endorsing the statement on faculty status," s27, s109; correction, s65

Other Books of Interest to Academic Lns., 61-62; 140-4I; $218-20 ; 303$; 380-82; 461-62

"Overdue policies: a comparison of alternatives," Baaske, Tolliver and Westerberg, 354-59

"An overlooked cost of achieving a participatory environment," Axford, editorial, 5-6; comment, 211-12; 295-96

\section{$\mathrm{P}$}

Painter, Ann F., "Change! Change! Change!," editorial, 161-62

Palmour, Vernon E., Bellassai, Marcia C., and Gray, Lucy M., Access to 'Periodical 'Resources: A National Plan, rev. of, 457 58

Palmour, Vernon E, Olson, Edwin E., and Roderer, Nancy K. Methods of Financing Interlibrary Loan Services, rev. of, $457-58$

Pasternack, Howard, rev. (Application of Computer Technology to L. Processes), 135-36
Pearson, Neville P. and Butler, Lucius A., Learning Resources Centers: Selected Readings, rev. of, 58-59

Peep, L. and K. Sinkevicius, "Financing system of USSR univ. ls.," 178-83; comment, 371

Penninger, E. Lorraine, 'Librarian honored for teaching excellence,"s305

People, s16-19; s43; s65-66; s8991 ; s117-18; s141-43; s168-69 s199-203; s237-39; s263-65; s307-9

Planning - Programming - Budget System (PPBS): Implications for L. Management, Lee, ed. rev. of, 215-16

Pownall, David, correction, 532

Proceedings of the 1972 Clinic on L. Applications of Data Processing: Applications of OnLine Computers to L. Problems, Lancaster, ed., rev. of 134

Proceedings of the 1973 Clinic on L. Applications of Data Processing: Network and Other Forms of Cooperation, rev. of, 380

"Project 1. ripoff: a study of periodical mutilation in a univ. 1.," Hendrick and Murfin, 40211

Publications, s14-15; s38-42; s6364; s83-87; s106-7; s135-36; s163-68; s193-97; s227-31 s260-62; s279-80

Pulsifer, Josephine S.. and Becker, Applications of Computer Technology to L. Processes: A Syllabus, rev. of, 135-36

\section{Q}

R

Raffel, Jeffrey A., "From economic to political analysis of 1. decision making," 412-23

"Ranking structure instituted in Duke Is.," s216

"Rate of growth for 1. collections," Heinritz, 95-96

Rawski, Conrad, ed. Toward a Theory of Librarianship: $P a$ pers in Honor of Jesse Hauk Shera, rev. of, $57-58$; comment, 213

Reader in Government Documents, O'Hara, ed., rev. of, 140

Reader in L. Cooperation, Reynolds, rev. of, 137-39

Reader in Medical Librarianship. Sewell, ed., rev. of, 60-61

Recent Publications, 55-68; 13441 ; 214-23; 299-306; 372-82; $457-62$

"Reference-bibliographers in the coll. 1.," Gration and Young, 28-32; comment, 133; 212, 213

Reference Services for Undergraduate Students: Four Case Studies, Wilkinson, rev. of 216-17

Research Collections in Canadian Ls., National $L$, of Canada. Resources Survey Section, rev. of, 459-60

Research Ls. Group, "RLG chooses director, gets Mellon grant," s213-15

Research Ls. and Technology: A Report to the Sloan Foundation, Fussler, rev. of, 375-76

Retirements, s19; s43; s66; s91; s118; s143; s202; s239; s265; s309
Reynolds, Elsie, rev. (Reference Services for Undergraduate Students), 216-17

Reynolds, Michael M., "Library cooperation: the ideal and the reality," 424-31; Reader in $L$. Cooperation, rev. of, 137-39

Richards, James H., Jr., port. \& prof., s 199

Rift, Leo R., letter to the ed., 4748

Roderer, Nancy K., Palmour and Olson, Methods of Financing Interlibrary Loan Services, rev. of, 457-58

"The role of circulation services in the major univ. 1.," Miller (CURL, Nov. 1973), comment, 212

Rowe, Judith S, and Mary Ryan, "Library service from numerical data bases: the 1970 census as a paradigm," 7-15

Ryan, Mary and Rowe, "Library service from numerical data bases: the 1970 census as a paradigm," 7-15

\section{S}

Sable. Martin H. International and Area Studies Librarianship, Case Studies, rev. of, 372

Saffady, William, "A univ. archives and records management program: some operational guidelines," 204-10

Scott, Barbara G., port. \& prof., 5237

Segre, Rose, "University ]s. in Italy: the crisis persists," 18491

"Selected reference books of 1972-73," Sheehy, 35-46

"Selected reference books of 1973-74," Sheehy, 242-51

Sewell, Winifred, ed., Reader in Medical Librarianship, rev. of, 60-6I

Sheehy, Eugene P., "Selected reference books of 1972-73," 3546; "Selected reference books of 1973-74," 242-51

Shera, Jesse H., letter to the ed, 213

Shockley, Ann Allen, "Black book reviewing: a case for 1 . action," 16-20

"Siberian Folklore," s87

Simon, John Y., "Editorial projects as derivative archives," 291-94

Sinkevicius, $K$. and Peep, "Financing system of USSR univ. Is.," 178-83; comment, 371

Smith, Harriet W., letter to the ed., 48

Smith, Jessie Camey. "Special collections of black literature in the traditionally black coll.," 322-35

Sources of Information in the Social Sciences: $A$ Guide to the Literature, 2 ed., White, rev. of, $372-73$

Sparks, Rita, letter to the ed., 296-97

"Special collections of black literature in the traditionally black coll.," Smith, 322-35

Sproat, Anabel, letter to the ed., 133

"State Postsecondary Education Commissions," s 198

"State-wide contracts for 1. materials: an analysis of the attendant dysfunctional consequences," Boyer, 86-94

Stevens, Charles H., port. \& prof., s 168 
Stevens, Norman D., rev. (Strategies for Change in Information Programs), 376; rev. (Toward a Theory of Librarianship), 57-58; comment, 213

Stevens, Rolland E., "A study of interlibrary loan," $336-43$

Stimson, Catherine R, Discrimination Against Women: Congressional Hearings on Equal Rights in Education and Employment, rev. of, 59-60

Strategies for Change in Information Programs, Hug, rev. of 376

"A study of interlibrary loan," Stevens, 336-43

"A study of job satisfaction in six univ. Is.," Vaughn and Dunn, 163-77

Stueart, Robert D., The Area Specialist Bibliographer: An Inquiry into His Role, rev. of 56-57; "EXCHANGE, anyone?," editorial ( $C \& R L$, Sept. 1973), comments, 51,52 ; rev. (The Doctoral Dissertation as an Information Source: A Study of Scientific Information Flow), 374-75

"The Supreme Court Obscenity Decisions," s54

A System for Inter-L. Communication (SILC), Hayes, rev. of, $457-58$

\section{$\mathrm{T}$}

Tanis, Norman E., "Annual report of the president, 197374," s 154-57

Targets for Research in L. Education, Borko, rev. of, 139

Tarr, Susan Akerstrom, "Effective group process for ls.: a focus on committees," 444-52

"Task force on women job roster," s 180

Taylor, James B., letter to the ed. 51

"Ten-year cumulation of Choice announced," s109

Terwilliger, Gloria, rev. (Film $L$ Technigues), 302-3

Thomas, Bruce E., letter to the ed., 51-52
" $\$ 350,000$ grant awarded to ACRL for Black Administrators Program," s25

Tilton, James J., letter to the ed., 212

Tjaden, Margaret, rev, (Discrimination Against Women), 59-60

"To our readers . . . ," $s 271$

Tolliver, Don L., Westerberg and Baaske, "Overdue policies: a comparison of altermatives," 354-59

"Too many chemistry journals," 268-69

Toward a Theory of Librarianship: Papers in Honor of Jesse Hauk Shera, Rawski, rev. of, 57-58; comment, 213

"Two-year guidelines in $\mathbf{A}-\mathbf{V}$ format," s113

\section{$\mathrm{U}$}

The Universal Decimal Classifcation: The History, Present Status, and Future Prospects of a Large General Classification Scheme, Foskett, rev. of, 37879

"A univ. archives and records management program: some operational guidelines," Saffady, 204-10

"University ls, in Italy: the crisis persists," Segre, 184-91

\section{V}

Vaughn, William J. and J. D. Dunn, "A study of job satisfaction in six univ. 1s.," 163-77

Veaner, Allen B., rev, (Auerbach on Microfilm Readers/Printers), 55-56

"Videotape on academic 1. governance available on loan," s262

\section{W}

Walton, Clyde C., "Access denied? the use of manuscript material," introduction, 285
Watson, Peter G., rev. (Proceedings of the 1973 Clinic on $L$. Applications of Data Processing), 380

Watson, Peter G., and Mathies, Computer-Based Reference Service, rev. of, 379-80

Weber, David C., "The dynamics of the 1. environment for professional staff growth," 259-67

Webster, Duane E., "The management review and analysis program: an assisted self-study to secure constructive change in the management of research 1s.," 114-25

Westerberg, Judy, Baaske and Tolliver, "Overdue policies: a comparison of alternatives," 354-59

White, Carl M. and others, Sources of Information in the Social Sciences: A Guide to the Literature, 2 ed., rev. of, $372-$ 73

Wilkinson, Billy R., Reference Services for Undergraduate Students: Four Case Studies, rev. of, 216-17

Williams, Harold, Book Clubs d Printing Societies of Great Britain and Ireland, rev. of, 377ain

Williams \& Wilkins, "Librarians win Williams \& Wilkins reversal," s27

Williamson, W. L., rev. (British Academic Ls.), 214-15

Wilson, Carol Dugan, and Burke, The Monthly Catalog of U.S. Government Publications; an Introduction to Its Use, rev, of, 134-35

\section{X-Y-Z}

Young, Arthur P., letter to the ed., 133

Young, Arthur P. and Gration, "Reference-bibliographers in the coll. 1.,"28-34; comment, $133,212-13$

Yun, Jai L., letter to the ed., 212 . 
The Technology Application Center of

The University of New Mexico

Telephone 505/277-3622

\section{ENERGY INFORMATION CENTER}

Retrospective Bibliographies with Abstracts \& Indexes with quarterly updates and annual cumulations

Presently available

HEAT PIPE TECHNOLOGY
HYDROGEN ENERGY
NOISE POLLUTION
REMOTE SENSING QUARTERLY

In preparation

COAL

GAS TURBINE

ENERGY STORAGE

SOLAR

WIND
Proposed

GEOTHERMAL
NUCLEAR
OCEAN \& TIDE
MAGNETOHYDRODYNAMICS (MHD)
COAL GASIFICATION
ELECTRIC POWER TRANSMISSION
OIL SHALE
WASTE HEAT

GEOTHERMAL

NUCLEAR

\& TIDE

MAGNETOHYDRODYNAMICS (MHD)

ION

OIL SHALE

WASTE HEAT

Other bibiographies \& symposia

\section{WASTE GLASS UTILIZATION \\ SYMPOSIUM ON UTILIZATION OF WASTE GLASS \\ NATURAL RESOURCES ON INDIAN RESERVATIONS (bimonthly) \\ ROLAMITE}

\section{. . . Short courses conducted irregularly}

The Technology Application Center provides literature search services for academia, government and industry. Presently drawing on about fifty automated data bases, TAC performs retrospective and current awareness literature searches in the sciences, social sciences, humanities, business, and the arts. TAC is a primary distributor for the Gemini. Apollo, and Skylab photographs for NASA, has catalogues available of the photographs, and is developing Educational Kits from the photographs.

Technology Application Center

The University of New Mexico

Albuquerque, N.M. 87131

Attention: Eugene Burch

Name

Organization

Address
Please send me information on the following:

Heat Pipe Technology

Hydrogen

Noise Pollution

Remote Sensing Quarterly Other (specify)

Literature searching

NASA photography

Educational Kits 


\section{Essential for every
academic library.}

Subject Collections. New 4th edition, available now.

Here's your guide to some 70,000 special collections in university, college, public and special libraries. The Bible. Banks and Banking. Polynesian art. English ballads. Whatever the interest, you'll be able to locate virtually every special library collection in the U.S., Canada, and Puerto Rico. And, for the first time, you'll find listings for many special museum holdings.

Entries, now arranged by Library of Congress headings, include name, location, curator, and number of holdings, plus all-important copying and inter-library loan details.

1974. Lee Ash, Editor. \$38.50.

Directory of American Scholars. Expanded 6th edition.

Keep pace with the academic community. Here, more than 37,000 men and women working in all areas of the humanities, are profiled. The people making news ... the individuals who have achieved status and responsibility ... the leaders in their fields.

For each alphabetically arranged entry, you'll find complete personal data plus information on fields of interest, degrees, major publications, and honors.

1974. Volume I. History. Volume II. English, Drama, and Speech. Volume III. Foreign Languages, Linguistics, and Philology. Volume IV. Philosophy, Religion, and Law. Indexed. $\$ 39.50$ per volume, or $\$ 148.50$ per set.

Order now on 30-day approval: R.R. Bowker Company, Box 1807, Ann Arbor, Michigan 48106. A Xerox Education Company. 
STANDARD 3:

Organization of Materials

3 Library collections shall be organized by nationally approved conventions and arranged for efficient retrieval at time of need.

3.1 There shall be a union catalog of the library's holdings that permits identification of items, regardless of format, by author, title, and subject.

3.1.1 The catalog may be developed either proprietarily by a single library or jointly among several libraries.

3.1.2 The catalog shall be in a format that can be consulted by a number of people concurrently and at time of need.

3.1.3 In addition to the catalog there shall also be requisite subordinate files, such as serial records, shelf lists, authority files, and indexes to non-monographic materials.

3.2 Except for certain categories of material which are for convenience best segregated by form, library materials shall be arranged on the shelves by subject.

3.2.1 Patrons shall have direct access to library materials on the shelves.

\section{Commentary on Standard 3}

The acquisition alone of library materials comprises only part of the task of providing access to them. Collections must be indexed and systematically arranged on the shelves before their efficient identification and retrieval at time of need, which is an important test of a good library, can be assured. For most library materials this indexing can best be accomplished through the development of a union catalog with items entered in accord with established national or international bibliographical conventions, such as rules for entry, descriptive cataloging, filing, classification, and subject headings.

Opportunities of several kinds exist for the cooperative development of the library's cata$\log$, through which economy can be gained in its preparation. These include the use of centralized cataloging by the Library of Congress and the joint compilation of catalogs by a number of libraries. Joint catalogs can take the form of card files, book catalogs, or computer files. Catalogs jointly developed, regardless of format, can satisfy this Standard provided that they can be consulted-under author, title, or subject-by a number of library users concurrently at their time of need. Catalogs should be subject to continual editing to keep them abreast of modern terminology, current technology, and contemporary practice.

Proper organization of the collections will also require the maintenance of a number of subordinate files, such as authority files and shelf lists, and of complementary catalogs, such as serial records, all of which should also be available to library users. In addition, some library materials such as journals, documents, and microforms are often indexed centrally by commercial or quasi-commercial agencies, and in such cases access should be provided to those indexes as needed, whether they be in published or computer-based format.

Materials should be arranged on the shelves by subject matter so that related information can be consulted together. Some kinds of materials, however, such as maps, microforms, and non-print holdings, may be awkward to integrate physically because of form and may be segregated from the main collection. Other materials, such as rarities and manuscripts or archives, may be segregated for purposes of security. Materials in exceptionally active use, such as bibliographies, works of reference, and assigned readings, may be kept separate to facilitate access to them. Except in such cases, however, the bulk of the collections should be classified and shelved by subject in open stack areas so as to permit and encourage browsing.

\section{STANDARD 4:}

STAFF

$4 \quad$ The library staff shall be of adequate size and quality to meet agreed-upon objectives.

4.1 The staff shall comprise qualified librarians, skilled supportive personnel, and part-time assistants serving on an hourly basis.

4.2 The marks of a librarian shall include a graduate library degree from an ALA-accredited program, responsibility for duties of a professional nature, and participation in professional library affairs beyond the local campus.

4.2.1 The librarians of a college shall be organized as an academic department-or, in the case of a university, as a schooland shall administer themselves in accord with ACRL "Standards for Faculty Status for College and University Librarians."

4.3 The number of librarians required shall be determined by a formula (Formula B) which takes into account the enrollment of the college and the size and growth rate of the collections.

4.3.1 There shall be an appropriate balance of effort among librarians, supportive personnel, and part-time assistants, so that every staff member is employed as nearly as possible commensurate with his library training, experience, and capability.

4.4 Library policies and procedures concerning staff shall be in accord with sound personnel management practice. 


\section{FORMULA B-}

The number of librarians required by the college shall be computed as follows:

For each 500 , or fraction thereof, FTE students up to 10,000

For each 1,000 , or fraction thereof, FTE students above 10,000

1 librarian

For each 100,000 volumes, or fraction thereof, in the collection

1 librarian

For each 5,000 volumes, or fraction thereof, added per year

1 librarian

1 librarian

Libraries which provide 100 percent of these formula requirements can, when they are supported by sufficient other staff members, consider themselves at the A level in terms of staff size; those that provide 75-99 percent of these requirements may rate themselves as $B$; those with 55-74 percent of requirements qualify for a $C$; and those with 40-54 percent of requirements warrant a $D$.

\section{Commentary on Standard 4}

The college library will need a staff comprising librarians, supportive personnel, and part-time assistants to carry out its stated objectives. The librarian has acquired through his training in a graduate library school an understanding of the principles and theories of selection, acquisition, organization, interpretation, and administration of library resources. Supportive staff members have normally received specialized or on-the-job training for particular assignments within the library; such assignments can range in complexity from relatively routine or business functions to highly technical activities often requiring university degrees in fields other than librarianship. Well managed college libraries also utilize some parttime assistants, many of whom are students, to perform repetitive and more perfunctory work; given good training and adequate experience such assistants can often perform at relatively skilled levels and constitute an important segment of the library team.

Work assignments, both to these several levels and to individuals, should be carefully conceived and allocated so that every member of the library staff is employed as nearly as possible commensurate with his library training, experience, and capability. This will mean that librarians will seldom comprise more than 2535 percent of the total FTE library staff.

The librarians of a college comprise the faculty of the library and should organize and administer themselves as any other departmental faculty in the college (or in the case of the university, the library faculty is equivalent to a school faculty, and should govern itself accordingly). In either case, however, the status, responsibilities, perquisites, and governance of the library faculty shall be fully recognized and supported by the parent institution, and it shall function in accord with the ACRL "Standards for Faculty Status for College and University Librarians."

The staff represents one of the library's most important assets in support of the instructional program of the college. Careful attention is therefore required to proper personnel management policies and procedures. Whether administered centrally for the college as a whole or separately within the library, these policies and practices must be based upon sound, contemporary management understanding consistent with the goals and purposes of the institution. This will mean that:

1. Recruitment methods should be based upon a careful definition of positions to be filled, utilization of a wide range of sources, qualifications based upon job requirements, and objective evaluation of credentials.

2. Written procedures should be followed in matters of appointment, promotion, tenure, dismissal, and appeal.

3. Every staff member should be informed in writing as to the scope of his responsibilities and the individual to whom he is responsible.

4. Classification and pay plans should give recognition to the nature of the duties performed, training and experience required, and rates of pay and benefits of other positions requiring equivalent background.

5. The library should provide a structured program for the orientation and training of new staff members and opportunities for the continuing education of existing staff.

6 . The library should select its supervisory staff on the basis of job knowledge and human relations skills and provide training in these responsibilities as needed.

7. The library should maintain a system for periodic review of employee performance and for recognition of achievement.

8. Career opportunities and counseling should be made available to library staff members at all levels and in all departments.

\section{STANDARD 5: \\ Delivery of Service}

The college library shall establish and maintain a range and quality of services that will promote the academic program of the institution and encourage optimal library use. 
5.1 Proper service shall include: the provision of continuing instruction to patrons in the effective exploitation of libraries; the guidance of patrons to the library materials they need; and the provision of information to patrons as appropriate.

5.2 Library materials shall be circulated to qualified patrons under equitable policies and for as long periods as possible without jeopardizing their availability to others.

5.2.1 The availability of reading materials shall be extended wherever possible by the provision of inexpensive means of photocopying.

5.2.2 The quality of the collections available locally to patrons shall be enhanced through the use of the ALA Interlibrary Loan Code and other cooperative agreements which provide reciprocal access to multi-library resources.

5.3 The hours of public access to the materials on the shelves, to the study facilities of the library, and to the library staff, shall be consistent with reasonable demand, both during the normal study week and during weekends and vacation periods.

5.4 Where academic programs are offered away from a campus, library services shall be provided in accord with ACRL's "Guidelines for Library Services to Extension Students."

\section{Commentary on Standard 5}

The primary purpose of college library service is to promote the academic program of the parent institution. The successful fulfillment of this purpose will require that librarians work closely with teaching faculty to gain an intimate knowledge of their educational objectives and methods and to impart to them an understanding of the services which the library can render. Both skill in library use and ease of access to materials can encourage library use, but the major stimulus for students to use the library has always been, and likely always will be, the instructional methods used in the classroom. Thus close cooperation between librarians and classroom instructors is essential.

Such cooperation does not come about fortuitously; it must be a planned and structured activity, and it must be assiduously sought. It will require not only that librarians participate in the academic planning councils of the institution but also that they assist teaching faculty in appraising the actual and potential library resources available, work closely with them in developing library services for new courses and new pedagogical techniques, and keep them informed of new library capabilities.

A key service of a college library is the interpretation of library materials to patrons.
Such interpretation will take one or more of three forms. The first is instruction in bibliography and information tools and in the use of the library's services. Such instruction may be given at many levels of sophistication and in many ways. The simplest group instruction may be tours or film presentations. Class instruction has also been found useful, especially when integrated with or closely related to regular course work. Programmed instructional packages that can be utilized by individual patrons when needed are also frequently helpful.

The second basic form which interpretation will take is conventional reference work wherein individual patrons are guided by librarians in their appraisal of the range and extent of the library resources available to them for learning and research, in the most effective marshalling of that material, and in the optimal utilization of libraries. This is the nature of most library interpretation.

The third major genre of library interpretative work is the delivery of information itself. Although obviously inappropriate in the case of student searches which are purposeful segments of classroom assignments, the actual delivery of information-as distinct from guidance to it-is a reasonable library service in almost all other conceivable situations. Such interpretative activities should be accomplished in accord with the "Developmental Guidelines for [Reference Services in] Small and Medium-sized Libraries," prepared by ALA's Reference and Adult Services Division.

As regards the circulation of library materials, the general trend in recent years has been toward longer loan periods, but these periods must be determined by local conditions which will include size of the collections, the number of copies of a book held, and the extent of the user community. Circulation should be for as long periods as are reasonable without jeopardizing access to materials by other qualified patrons. This overall goal may prompt some institutions to establish variant or unique loan periods for different titles or classes of titles. Whatever loan policy is used, however, it should be equitably and uniformly administered to all qualified categories of patrons.

Locally-held library resources should be extended and enhanced in every way possible for the benefit of library patrons. Both the quantity and the accessibility of reading materials can be extended through the provision of inexpensive means of photocopying within the laws regarding copyright. Local resources should also be extended through the provision and encouragement of reciprocal arrangements with other libraries as through the ALA Interlibrary Loan Code and joint-access consortia. Beyond its own local constituency every library also has a responsibility to make its holdings available to other students and scholars in at least three 
ways-in-house consultation, photocopy, and through interlibrary loan-to the degree that these courtesies are reciprocated.

The number of hours per week that library services should be available will vary, depending upon such factors as whether the college is in an urban or rural setting, teaching methods used, conditions in the dormitories, and whether the student body is primarily resident or commuting. In any case, library scheduling should be responsive to reasonable local need, not only during term-time week-days but also on weekends, and, especially where graduate work is offered, during vacation periods. In many institutions readers may need access to study facilities and to the collections during more hours of the week than they require the personal services of librarians. The public's need for access to librarians may range upward to one hundred hours per week, whereas around-the-clock access to the library's collections and/or facilities may in some cases be warranted.

Special library problems exist for colleges that provide off-campus instructional programs.
Students in such programs must be provided with library services in accord with ACRL's "Guidelines for Library Services to Extension Students." These Guidelines require that such services be financed on a regular basis, that a librarian be specifically charged with the delivery of such services, that the library implications of such programs be considered before program approval, and that courses so taught encourage library use. Such services, which are especially important at the graduate level, must be furnished despite their obvious logistical problems.

\section{STANDARD 6 : FACILITIES}

6 The college shall provide a library building containing secure facilities for housing its resources, adequate space for administration of those resources by staff, and comfortable quarters and furnishings for their utilization by patrons.

6.1 The size of the library building shall be determined by a formula (Formula C) which takes into account the enrollment of

\section{FORMULA C-}

The size of the college library building shall be calculated on the basis of a formula which takes into consideration the size of the student body, requisite administrative space, and the number of physical volumes held in the collections. In the absence of consensus among librarians and other educators as to the range of non-book services which it is appropriate for libraries to offer, no generally applicable formulas have been developed for calculating space for them. Thus, space required for a college library's non-book services and materials must be added to the following calculations:

a. Space for readers. The seating requirement for the library of a college wherein less than fifty percent of the FTE enrollment resides on campus shall be one for each five FTE students; the seating requirement for the typical residential college library shall be one for each four FTE students; and the seating requirement for the library in the strong, liberal arts, honors-oriented college shall be one for each three FTE students. In any case, each library seat shall be assumed to require twenty-five square feet of floor space.

b. Space for books. Space required for books depends in part upon the overall size of the book collection, and is calculated cumulatively as follows:

For the first 150,000 volumes

Square Feet/Volume

For the next 150,000 volumes

For the next 300,000 volumes

For holdings above 600,000 volumes

0.07

c. Space for administration. Space required for such library administrative activities as acquisition, cataloging, staff offices, catalogs, and files shall be one-fourth of the sum of the spaces needed for readers and books as calculated under (a) and (b) above.

This tripartite formula indicates the net assignable area necessary for all library services except for non-book services. (For definition of "net assignable area" see Library Statistics Operations Handbook.) Libraries which provide 100 percent as much net assignable area as is called for by the formula shall qualify for an A rating as regards quantity; 75-99 percent shall warrant a $B$; $60-74$ percent shall be due a $C$; and $50-59$ percent shall warrant a $\mathrm{D}$. 
the college, the extent and nature of its collections, and the size of its staff.

6.2 The shape of the library building and the internal distribution of its facilities and services shall be determined by function.

6.3 The esthetic and physical characteristics of the library building shall harmonize with its function and shall be pleasing to the senses.

6.4 Except in unusual circumstances, the college library's collections and services shall be administered within a single structure.

\section{Commentary on Standard 6}

Successful library service presupposes an adequate library building. Although the type of building provided will depend upon the character and the aims of the institution, it should in all cases present secure facilities for housing the library's resources, sufficient space for their administration by staff, and comfortable quarters and furnishings for their utilization by the public, all integrated into a functional and esthetic whole. The college library building should represent a conscious planning effort, involving the librarian, the college administration, and the architect, with the librarian responsible for the preparation of the building program. The needs of handicapped patrons should receive special attention in the designing of the library building.

Many factors will enter into a determination of the quality of a library building. They will include such esthetic considerations as its location on the campus, the grace with which it relates to its site and to neighboring structures, and the degree to which it contributes esthetically to the desired ambience of the campus. They will also include such internal characteristics as the diversity and appropriateness of its accommodations and furnishings, the functional distribution and interrelationships of its spaces, and the simplicity and economy with which it can be utilized by patrons and operated by staff. They will include moreover such physical characteristics as the adequacy of its acoustical treatment and lighting, the effectiveness of its heating and cooling plant, and the selection of its movable equipment.

Decentralized library facilities on a campus have some virtues, and they present some difficulties. Primary among their virtues is their adjacency to the laboratories and offices of some teaching faculty members within their service purview. Primary among their weaknesses are their fragmentation of unity of knowledge, their relative isolation from library users (other than aforementioned faculty), the fact that they can seldom command the attention of qualified staff over either long hours during a week or over a sustained period of time, and the excessive costs of creating dupli- cate catalogs, periodical lists, circulation services, and attendant study facilities. Where decentralized library facilities are being considered, these costs and benefits must be carefully compared. In general, experience has shown that except where long distances are involved, decentralized library facilities are at the present time unlikely to be in the best pedagogical or economic interests of a college.

\section{STANDARD 7: \\ AdMinistration}

$7 \quad$ The college library shall be administered in a manner which permits and encourages the fullest and most effective use of available library resources.

7.1 The statutory or legal foundation for the library's activities shall be recognized in writing.

7.2 The college librarian shall be a member of the library faculty and shall report to the president or the chief academic offcer of the institution.

7.2.1 The responsibilities and authority of the college librarian and procedures for his appointment shall be defined in writing.

7.3 There shall be a standing advisory committee comprising students and members of the teaching faculty which shall serve as the main channel of formal communication between the library and its user community.

7.4 The library shall maintain written policies and procedure manuals covering internal library governance and operational activities.

7.4.1 The library shall maintain a systematic and continuous program for evaluating its performance and for identifying needed improvements.

7.4.2 The library shall develop statistics not only for purposes of planning and control but also to aid in the preparation of reports designed to inform its publics of its accomplishments and problems.

7.5 The library shall develop, seek out, and utilize cooperative programs for purposes of either reducing its operating costs or enhancing its services, so long as such programs create no unreimbursed or unreciprocated costs for other libraries or organizations.

7.6 The library shall be administered in accord with the spirit of the ALA "Library Bill of Rights."

\section{Commentary on Standard 7}

Much of the commentary on general administration of the college library is gathered under the several other Standards. Matters of personnel administration, for example, are discussed under Standard 4, and fiscal adminis- 
tration is glossed under Standard 8. Some important aspects of library management, however, must be considered apart from the other Standards.

Primary among administrative considerations which are not part of other Standards is the matter of the responsibilities and authority both of the library as an organization and of the college librarian as a college officer. No clear set of library objectives, no tenable program of collection development, no defensible library personnel policy can be developed unless there is first an articulated and widespread understanding within the college as to the statutory, legal or other basis under which the library is to function. This may be a college bylaw, or a trustee minute, or a public law which shows the responsibility and flow of authority under which the library is empowered to act. There must also be a derivative document defining the responsibility and authority vested in the office of the college librarian. This document may also be statutorily based and should spell out, in addition to the scope and nature of his duties and powers, the procedures for his appointment and the focus of his reporting responsibility. Experience has shown that, for the closest coordination of library activities with the instructional program, the college librarian should report either to the president or to the chief officer in charge of the academic affairs of the institution.

Although the successful college library must strive for excellence in all of its communications, especially those of an informal nature, with its publics, it must also have the benefit of an advisory committee representing its user community. This committee- of which the college librarian should be an ex officio member - should serve as the main channel of formal communication between the library and its publics, and should be used to convey both an awareness to the library of its users' concerns, perceptions, and needs, and an understanding to patrons of the library's capabilities and problems. The charge to the committee should be specific, and it should be in writing.

Many of the precepts of college library administration are the same as those for the administration of any other similar enterprise. The writing down of policies and procedures manuals, for example, is required for best management of any organization so as to assure uniformity and consistency of action, to aid in training of staff, and to contribute to public understanding. Likewise sound public relations are essential to almost any successful service organization. Although often observed in their omission, structured programs of performance evaluation and quality control are equally necessary. All of these administrative practices are important in a well managed library.
Some interlibrary cooperative efforts have on occasion tended in local libraries to enhance the quality of service or reduce operating costs. Labor-sharing, for example, through cooperative processing programs has been beneficial to many libraries, and participation in the pooled ownership of seldom-used materials has relieved pressure on some campuses for such materials to be collected locally. The potential values of meaningful cooperation among libraries are sufficient to require that libraries actively search out and avail themselves of cooperative programs that will work in their interests. Care should be taken, however, to assure that a recipient library reimburse, either in money or in kind, the full costs of any other institution that supplies it service, unless of course the supplying institution is specifically charged and funded so to make its services available.

College libraries should be impervious to the pressures or efforts of any special interest groups or individuals to shape their collections and services in accord with special pleadings. This principle, first postulated by the American Library Association in 1939 as the "Library Bill of Rights," should govern the administration of every college library and be given the full protection of all parent institutions.

\section{Standard 8: \\ BUDGET}

8 The college library shall have the responsibility for preparing, defending, and administering its budget in accord with agreedupon objectives.

8.1 The amount of the library appropriation shall express a relationship to the total institutional budget for educational and general purposes.

8.2 The library shall have sole authority to apportion funds and initiate expenditures within its approved budget.

8.3 The library shall maintain internal accounts, approve its invoices for payment, and monitor and evaluate the flow of its expenditures.

\section{Commentary on Standard 8}

The library budget is a function of program planning and tends to define the library's objectives in fiscal terms and for a stated interval of time. Once agreed to by the college administration, the objectives formulated under Standard I should constitute the base upon which the library's budget is developed. The degree to which the college is able to fund the library in accord with its objectives is reflected in the relationship of the library appropriation to the total educational and general budget of the college. Experience has shown that library budgets, exclusive of capital costs and the costs of physical maintenance, which fall below six per- 
cent of the college's total educational and general expenditures are seldom able to sustain the range of library programs required by the institution. This percentage moreover will run considerably higher during periods when the library is attempting to overcome past deficiencies or to raise its "grade" on collections and staff as defined elsewhere in these Standards.

The adoption of formulas for preparation of budget estimates and for prediction of library expenditures over periods of time are relatively common, especially among public institutions. Since such formulas can often provide a gross approximation of needs, they are useful for purposes of long-range planning, but they frequently fail to take into account local cost variables, and they are seldom able to respond promptly to unanticipated market inflation or changes in enrollment. Thus they should not be used, except as indicators, in definitive budget development.

Among the variables which should be considered in estimating a library's budget requirements are the following:

1. The scope, nature, and level of the college curriculum;

2. Instructional methods used, especially as they relate to independent study;

3. The adequacy of existing collections and the publishing rate in fields pertinent to the curriculum;

4. The size, or anticipated size, of the student body and teaching faculty;

5. The adequacy and availability of other library resources in the locality to which the library has contracted access;

6. The range of services offered by the library, the number of service points maintained, the number of hours per week that service is provided, etc.;

7. The extent to which the library already meets the Standards defined in these pages.

Procedures for the preparation and defense of budget estimates, policies on budget approval, and regulations concerning accounting and expenditures may vary from one institution or jurisdiction to another, and the college librarian must know and conform to local practice. In any circumstances, however, sound practices of planning and control require that the librarian have sole responsibility and authority for the allocation-and within college policy, the reallocation-of the library budget and the initiation of expenditures against it. Depending upon local factors, between 35 and 45 percent of the library's budget is normally allocated to the purchase of materials, and between 50 and 60 percent is expended for personnel.

The preparation of budget estimates may be made on the basis of past expenditures and an- ticipated needs, comparison with similar libraries, or statistical norms and standards. More sophisticated techniques for detailed analysis of costs by library productivity, function, or program-as distinct from items of expenditure-have been attempted in some libraries. Such procedures require that the library develop quantitative methods by which to prepare estimates, analyze performance, and determine the relative priority of services rendered. Although this kind of budgeting, once refined, may lead to more effective fiscal control and greater accountability, libraries generally have thus far had too limited experience with program budgeting or input-output analysis to permit their widespread adoption at this time.

Hearings on this draft will be held in Chicago during the ALA Midwinter Meeting, on Monday, January 20, 2:00-4:00 p.m., and on Tuesday, January 21, 2:00-4:00 p.m.

Comments on the draft may be directed to the committee members.

Reprints of this article are available from the ACRL Office, 50 E. Huron St., Chicago, IL 60611.

\section{LIBRARIAN HONORED FOR TEACHING EXCELLENCE}

E. Lorraine Penninger has received one of the 1974 North Carolina National Bank Awards for teaching excellence at the University of North Carolina, Charlotte. NCNB gives the university an annual grant to honor its outstanding teachers. Nominations are made by students, fellow faculty members, or alumni; each recipient receives a cash grant of $\$ 1,000$ plus a framed citation.

Mrs. Penninger is head of the reference department in UNCC's Atkins Library. A graduate of Flora MacDonald College and the University of Denver, she holds the rank of assistant professor.

The award was presented on September 20 by C. James Nelson, an executive vice-president of NCNB, at a dinner honoring the UNCC faculty and their husbands and wives. Mrs. Penninger was honored for teaching students by helping them with their library research. "I don't have regular classes, but I am trying to get into the classrooms to teach students how to do their research better," she said.

Mrs. Penninger was the first nonteaching faculty member to receive the award. 